\title{
Tyrosine Kinase level and White Blood Cells Count in Untreated and Treated Chronic Myelogenous Leukemia Patients with $B C R A B L$ gene
}

\author{
Delita Prihatni ${ }^{1}$, Rachmat Sumantri ${ }^{2}$, Rully Roesli ${ }^{3}$, Nadjwa Zamalek Dalimonthe ${ }^{4}$, Ida Parwati ${ }^{5}$ \\ ${ }^{1,4,5}$ Universitas Padjadjaran/Dr Hasaan Sadikin General Hospital/Dept SMF of Clinical Pathology \\ ${ }^{2,3}$ Universitas Padjadjaran/Dr Hasaan Sadikin General hospital/Dept SMF of Internal Medicine
}

\begin{abstract}
Background: Molecularly, Chronic Myelogenus Leukemia (CML) is defined by the Philadelphia chromosome, t(9;22) (q34; 11.2), which encodes the BCR-ABL1 fusion protein, that disturb the function of tyrosine kinase. Role of tyrosine kinase activity in the cell, include cell-cycle control, transcription process, and mitogenesis, or induction of cell's mitosis. These properties generate the use of Tyrosine Kinase Inhibitor for CML treatment through inhibition of signal transduction. The aim of this study is to find out the correlation between Tyrosine Kinase level as a mediator of signal transduction with the white blood cells count in untreatedand treated patients with CML. Subject and methods: This study was held on January-July 2014 in Clinical Pathology Laboratory of Dr Hasan Sadikin General Hospital Bandung, Indonesia. Subjects were divided into two groups: untreated group and treated group after treatments for CML. Chronic Myelogenus Leukemia is diagnosed if BCR-ABL gene is detected using Reverse Transcriptase-Polymerase Chain Reaction technique. Complete blood count was done using Sysmex XT2100i, while tyrosine kinase level was analyzed by Enzymelinked Immunosorbent Assay technique. Data were analyzed with Wilcoxon signed-rank test, and Spearman's analysis. Results: Subject enrolled in this study were 57 CML patients, consist of 34 male and 23 female. We found a significant positive correlation between the number of white blood cell with Tyrosine Kinase level $(r=0.456 ; p<0.001)$ in both untreated and treated group. The level of Tyrosine Kinase and white blood cells count significantly higher in untreated CML patients compared to treated group. No significant different were found in, Red Blood Cells and platelet cells count within two groups. Conclusions: This study shown correlation between the numbers of WBC with level of Tyrosine Kinase, in untreated and treated CML patients.
\end{abstract}

Keywords: CML, Tyrosine kinase, white blood cells count

\section{Introduction}

In 1951 William Dameshek stated that Chronic myelogenous leukemia (CML) are included in the class of myeloproliferative disorder characterized by an increase number of cells in the peripheral blood as a result of increase activity of bone marrow proliferation. Chronic myelogenous leukemia (CML) is the first malignancy known associated with genetic lesions, Philadelphia $(\mathrm{Ph})$ chromosome, in more than $95 \%$ of CML patients, which was discovered by Rowley in 1973. ${ }^{1,2}$ Philadelphia chromosome is formed by translocation between the 3' Abelson murine leukemia ( $A B L)$ gene which is considered to be an oncogen on the long arm of chromosome 9 band 9q34 (9q34) with the 5' Breakpoint Cluster Region (BCR) geneat chromosome 22with a breaking pointon band q11:22 (22q11) resulting chimeric Breakpoint Cluster Region-Abelson (BCR-ABL) gene which in virtually all cases results in the formation of a BCR-ABL protein. ${ }^{3-8}$ The BCR-ABL protein with a molecular mass of $210 \mathrm{kDa}$, contains the active tyrosine kinase region of ABL, produces a cytokine-independent, constitutive proliferative signal and affects a variety of down-stream pathways. Overexpression of BCR-ABL protein resulted in disregulation of Tyrosine Kinase (TK) activity and trigger leukemogenesis. ${ }^{6,9-11}$ Tyrosine Kinases are enzymes that play a role as mediator in the process of signal transduction for cell proliferation, differentiation migration, metabolism and apoptosis. ${ }^{12,13}$

Chronic myelogenous leukemia is characterized by loss of control of the process of hematopoiesis leading to excessive proliferation and differentiation on myeloid elements at all stages of maturation. Clinically, the patient will experience chronic phase, accelerated phase CML, and blast phase. The chronic phase is characterized by an abnormal proliferation of myeloid precursors. This is occurred due to small differences in maturation imbalances, and then excessive cell growth without abnormality of morphology. ${ }^{2}$

Tyrosine kinase inhibitors (TKIs) have proved to be a great advantage in the management of patients with CML in chronic phase. The drugs are a highly selective inhibitor of the protein tyrosine kinase family, which includes BCRABL protein, the platelet-derived growth factor (PDGF) receptor and the c-kit receptor. ${ }^{14}$ Treatment monitoring to TKI consist of hematology response (HR), Cytogenetic response (CyR), and molecular respons (MR). Fusion transcript levels of $B C R-A B L$ until a $>3 \log$ reduction (1000 fold reduction; $0.1 \% B C R-A B L$ gene according to the international scale (IS)) from the baseline mean, defined as a major molecular response (MMR). In term of treatment responses, it has been reported that this BCR-ABL kinase inhibitor produces a complete $\mathrm{HR}$ in $98 \%$ of patients. A laboratories complete HR was defined as, a white blood cell (WBC) count of less than $10 \times 10^{3} / \mu \mathrm{L}$, a platelet cells count of less than $450 \times 10^{3} / \mu \mathrm{L}$, and no detected mieloblast cells. ${ }^{15,16}$ The purpose of this study is to find out the relationship between TK enzyme activity level as a mediator of signal transduction and the WBC count in treated and untreated CML patients.

\section{Subject and Methods}

The study was conducted between December 2013 and July 2014. The subjects were 57 adult patients diagnosed with CML in the chronic phase and being examined for $B C R A B L$ gene quantification ratio in the laboratory of Clinical Pathology Department Dr. HasanSadikin General Hospital, 


\section{International Journal of Science and Research (IJSR) \\ ISSN (Online): 2319-7064}

Index Copernicus Value (2013): 6.14 | Impact Factor (2015): 6.391

which consists of, untreated and treated patients that has received various treatment. The characteristics of the subjects divided into two categories: Untreated group patients who have not received any treatments, and treated group patients, who were treated with various drugs for CML such as hydroxyurea or TKI. Patients signed written informed consent for their data to be used in this analysis. Diagnosis of CML was confirmed based on clinical manifestations, examination of complete blood count (the number of red blood cell (RBC), WBC and platelet cells) by hematology analyzer Sysmex XT 2100i. Diagnosis was confirmed by detection of the $B C R A B L$ gene with Reverse transcriptase-polymerase chain reaction(RT PCR) techniques and quantification ratio of $B C R A B L /$ Glucose-6Phosphate Dehydrogenase (G6PDH) gene. The level of TK enzyme was performed by Enzyme-linked Immunosorbent Assay (ELISA) method and statistical analysis by Wilcoxon signed-rank testand Spearman's, statistically significant if $p<0.05$.

\section{Sample Preparation}

Blood samples were collected in two EDTA vacutainer tubes, to CBC, TK and RT PCR test. For RT PCR test, cell lysed using $1 \mathrm{~mL}$ Red Blood Lyses Buffer, centrifuged for 5 minutes at $2500 \mathrm{G}$, discard the supernatant and add another $1 \mathrm{~mL}$ Red Blood Lyses Buffer. Centrifuged for 3 minutes, the supernatant was discarded and the pellet was added in $200 \mathrm{~mL}$ of Phosphate Buffer Saline (PBS) solution to obtain WBC.

\section{Ribonucleic Acid Extraction}

White blood cells and PBS solution were mixed. Trizol and chloroform were added with the ratio of $1: 1$. Incubated for three minutes, and then centrifuged $12,000 \mathrm{G}$ for 15 minutes at $4^{\circ} \mathrm{C}$, then it will form three layers. The top layer is taken about $450 \mu \mathrm{L}$ and transferred into a new tube and incubated with $188 \mu \mathrm{L}$ of isopropanol for 10 minutes, then centrifuged $12,000 \mathrm{G}$ for 10 minutes at $4^{\circ} \mathrm{C}$ and the supernatant was discarded, then $200 \mu \mathrm{L}$ ethanol $70 \%$ was added. The mixture then centrifuged $7500 \mathrm{G}$ at $4^{\circ} \mathrm{C}$ for 5 minutes. The supernatant was discarded and the pellet was dried, then, 75 $\mathrm{mL}$ of RNAse was added.

\section{Complementary Deoxyribo Nucleic Acid (cDNA)}

Ribonucleic Acid Extraction (RNA) was denatured at the temperature of $65^{\circ} \mathrm{C}$ for 10 minuets. Added to master mixreverse transcriptase, put into PCR machine which later incubated at $37^{\circ} \mathrm{C}$ for 1 hour and at $56^{\circ} \mathrm{C}$ for 10 minutes. The result of cDNA is used as comparative figures of quantitative examination of $B C R-A B L / G 6 P D H$ gene.

\section{Quantitative Polymerase Chain Reaction}

Quantification of $B C R-A B L$ gene was done by using LC $\mathrm{t}(9,22)$ quantification kit in the Light Cycler 1.5 to assess the comparative figures of $B C R-A B L / G 6 P D H$ gene as stable house keeping gene in humans. The sequence of the primers used:
Table 1: Primer of $B C R-A B L / G 6 P D H$ test

\begin{tabular}{|c|l|}
\hline $\begin{array}{c}\text { Gene } \\
\text { fusion }\end{array}$ & \multicolumn{1}{|c|}{ Primer } \\
\hline$b 2 a 2$ & BCR-b2 \\
& 5' -ACAGAATTCCGCTGACCATCAATAAG-3' \\
& ABL-a2 \\
& 5'-TGTTGACTGGCGTGATGTAGTTGCTTGG-3' \\
\hline$b 3 a 2$ & BCR-b2 \\
& 5'-ACAGAATTCCGCTGACCATCAATAAG-3' \\
& ABL-a2 \\
& 5'-TGTTGACTGGCGTGATGTAGTTGCTTGG-3' \\
\hline
\end{tabular}

The PCR products were analyzed on 3\% Agarose gel. Results confirmed positive if the value of Cycle threshold $(\mathrm{Ct})<40$ and the comparative figures of target $(B C R-A B L)$ gene compared is G6PDH gene $>0.0001$.

\section{Tyrosine Kinase Test}

$50 \mathrm{ml}$ of conjugate was added to each well and incubated for two hours at $37^{\circ} \mathrm{C}$. Microtiters were washed 5 times using liquid laundering and $50 \mathrm{ml}$ of substrate $\mathrm{A}$ and $\mathrm{B}$ are added to each well. They are then covered and incubated for 10 minutes at temperature of $20-25^{\circ} \mathrm{C}$, after that, $50 \mathrm{ml}$ of stop solution was mixed in to each well before reading the optical density at $450 \mathrm{~nm}$ using a microtiter plate reader.

\section{Results}

Haemoglobin level included to subject characteristic because it was not directly related to blood cell formation. All subject (untreated and treated group) still contain $B C R$ $A B L$ gene (table 2).

Table 2: Subject characteristics

\begin{tabular}{|l|c|c|}
\hline \multicolumn{1}{|c|}{ Characteristic } & $\begin{array}{c}\text { Untreated } \\
\text { patients } \\
(\mathrm{n}=31)\end{array}$ & $\begin{array}{c}\text { Treated } \\
\text { patients } \\
(\mathrm{n}=26)\end{array}$ \\
\hline Gender & & \\
\hline Male $(\%)$ & $18(0.58)$ & $16(0.62)$ \\
\hline Female (\%) & $10(0.38)$ & $13(0.42)$ \\
\hline Age (y.o) & 38.8 & 38 \\
\hline Hemoglobin $(\mathrm{g} / \mathrm{dL})$ & 8.98 & 10.29 \\
\hline Ratio of BCR ABL/G6PDH gene & 0.03693 & 0.05057 \\
\hline
\end{tabular}

Among hematology parameters (and the level of TK protein) were found positive correlation between the number of WBC ( $\mathrm{r} 0.26 ; \mathrm{p}=0.0158)$ and platelet cells ( $\mathrm{r} 0.16 ; \mathrm{p}=0.399)$ with the TK enzyme level. Negative correlation between the $\mathrm{RBC}$ count with the TK enzyme level $(\mathrm{r}-0.24 ; \mathrm{p}=0.190)$ (figure 1).

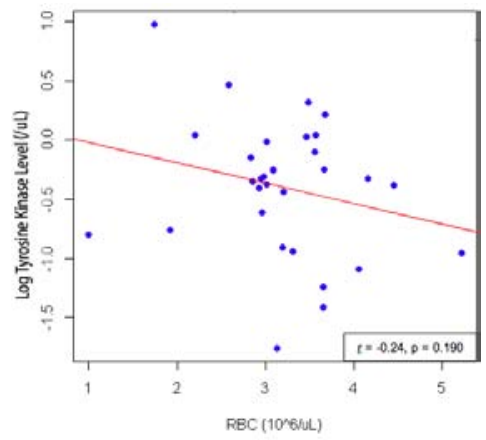




\section{International Journal of Science and Research (IJSR) \\ ISSN (Online): 2319-7064}

Index Copernicus Value (2013): 6.14 | Impact Factor (2015): 6.391

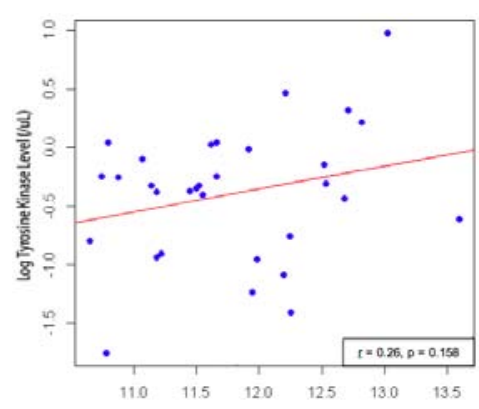

$\log W B C(N L)$

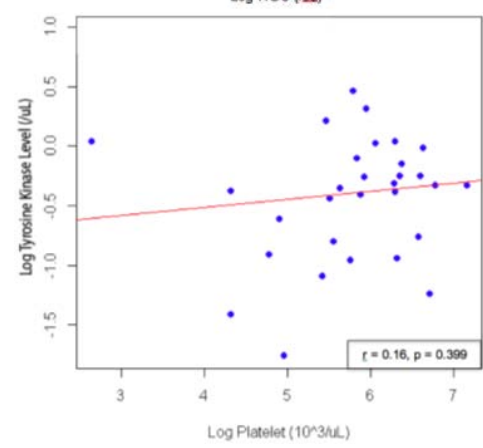

Figure 1: Correlation between the Tyrosine Kinase enzyme level and blood cells at untreated group patients
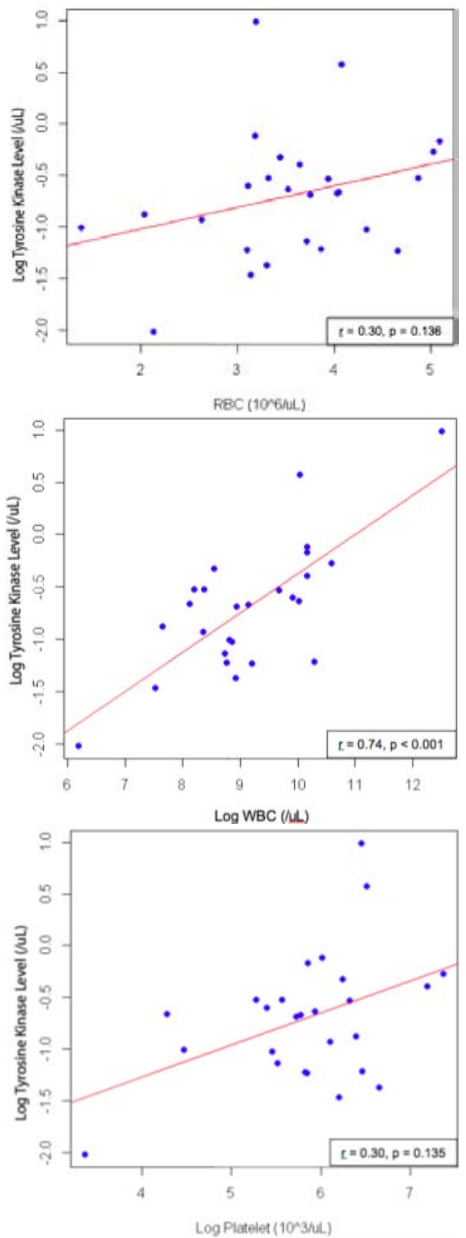

Figure 2: Correlation between the Tyrosine Kinase enzyme level and blood cells at treated group patient

A significant difference is found on the TK enzyme level $(\mathrm{p}<0.023)$ and the WBC count $(\mathrm{p}<0.001)$, and TK protein $(p=0.03)$ between untreated and treated group patients.
There is no significant difference in $\mathrm{Hb}$ level, number of $\mathrm{RBC}$ and platelet cells. (figure 1).

\section{Discussion}

Chronic Myeloid Leukemia as proliferative disorder characterized by the growth of blood cells that improves greatly especially WBC. In vitro and in vivo studies stated that the role of $B C R A B L$ gene as the main mediator of proliferation, apoptosis, transformation of stem cell (stem cell) CML. The mechanism of $B C R A B L$ gene induce growth factor has not yet been fully elucidated. The possible mechanisms include the activation of cytokine signal transduction pathways by $B C R-A B L$ gene and/or aberrant expression of cell cycle control genes, cytokine receptors, and the autocrine production of the growth factor by the cell itself. ${ }^{17}$ Tyrosine phosphorylation is one of the important processes that occurs in multicellular organisms as a result of intercellular communication during embryogenesis and to maintain adult tissues. ${ }^{1}$

In malignancy the transformation of function TK enzyme is change leading to activation signals of other proteins, which inhibit the function of the normal regulation of cell division, proliferation and apoptosis. The TK enzyme over activation caused mutations, such as point mutations or abnormal chromosomal translocation, as an important source of mutation in CML. ${ }^{12} B C R A B L$ gene transcription resulting in cell growth leukemogenic on hemopoiesis mediated by TK enzyme that play a role in signal transduction processes in the cell and CML cases characterized by increase the number of WBC and sometimes simultaneously with increases of the platelet cells. Signal transduction plays a role in mitogenesis process is a rat sarcoma viral oncogene homolog (RAS)/mitogen-activated protein kinase (MAPK) pathways, the janus kinase (JAK)/signal transducer and activator of transcription (STAT) pathway, phosphoinositide-3 (PI3) kinase pathway and the MYC pathway. ${ }^{17}$

Table 3: The number of blood cells and the Tyrosine Kinase enzyme level in untreated and treated patients

\begin{tabular}{|l|c|c|c|}
\hline Variable & $\begin{array}{c}\text { Untreated patient } \\
(\mathrm{n}=31)\end{array}$ & $\begin{array}{c}\text { Treated patient } \\
(\mathrm{n}=26)\end{array}$ & $p$ value \\
\hline $\begin{array}{l}\mathrm{RBC}(/ \mu \mathrm{L}), \text { median } \\
(\mathrm{IR})\end{array}$ & $\begin{array}{c}3,310,000 \\
(1,470,000)\end{array}$ & $\begin{array}{c}3,580,000 \\
(925,000)\end{array}$ & $0.798^{*}$ \\
\hline $\begin{array}{l}\text { Leukocytes}(/ \mu \mathrm{L}), \\
\text { median }(\mathrm{IR})\end{array}$ & $\begin{array}{c}115,460 \\
(138,330)\end{array}$ & $7,555(19,365)$ & $<0.001^{*}$ \\
\hline $\begin{array}{l}\text { Platelets }(/ \mu \mathrm{L}), \\
\text { median }(\mathrm{IR})\end{array}$ & $\begin{array}{c}358,000 \\
(339,000)\end{array}$ & $\begin{array}{c}363,500 \\
(360,750)\end{array}$ & $0.798^{*}$ \\
\hline $\begin{array}{l}\text { TK protein }(/ \mu \mathrm{L}), \\
\text { median }(\mathrm{IR})\end{array}$ & $0.72(0.54)$ & $0.51(0.37)$ & $0.023^{*}$ \\
\hline
\end{tabular}

- Wilcoxon signed-rank test

IR: Interquartile Range

The first available therapy was ionizing splenic irradiation, but in 1953 treatment options expanded to include busulphan. Several years later, hydroxyurea was introduced. In the mid-1980s a-interferon (IFN-a) was introduced as a treatment for CML. At 2001 Imatinib introduced as TKI prevented growth of haematopoietic cells that expressed BCR-ABL but did not affect normal cell function. ${ }^{14}$ Hematology response is the earliest respon therapy to achieve. Consistent with this research, it is found 


\section{International Journal of Science and Research (IJSR) \\ ISSN (Online): 2319-7064}

Index Copernicus Value (2013): 6.14 | Impact Factor (2015): 6.391

that the level of TK and the number of WBC decreased in CML patients that have been through therapies (Table 3). Treatment of CML originally focused on the control of leukemic cell mass. Overall around $60 \%$ of patients given imatinib achieve an excellent response, whereas $40 \%$ proceed to a second-line agent due to intolerance or inadequate response. Nilotinib and dasatinib achieve more rapid responses with first-line therapy and are therefore used in some centres, although side-effects are somewhat more common. They are also used as second-line therapy after imatinib. Bosutinib is also an effective second line therapy, whilst ponatinib has the unique advantage that it is effective against tumours that carry the T315I mutation within $B C R-A B L$ gene. $^{18}$

In fact, several studies demonstrate failure to the treatment of TKI, then progression to disease and resistance to drug. Conceptually, both the processes of progression and resistance can be tied to genetic instability. In this research, shown a significant decrease between tke TK enzyme level as a therapeutic target of TKI and the WBC count as a result of therapy, indicating that the subject is still responsive to TKI. If the therapy fails, it shows the implication of genetic instability is the rationale for more vigorous suppression of $B C R-A B L$ gene to activity of TK enzyme at the beginning of treatment.The second implication is that we need ways to predict response to therapy in both the upfront and resistance settings. ${ }^{19}$ Some studies suggest that the expansion of malignant CML cells is not directly affected by neoplastic stem cells but due to the line of progenitor cells myeloid lineage. In this study proves there is a relationship between the levels of TK and the WBC count, and significant correlation level of TK and $\mathrm{WBC}$ count between untreated and treated patients. This research did not distinguish the types of therapy leading to different target of therapy, which is the limitation of the research.

However, in the cases of persistent $B C R-A B L$ gene after TKI therapy that has reached complete cytogenetic response, allegedly TKI only inhibits progenitor cells while stem cells cannot be reached. This is also one of the reasons of blast fase on CML ${ }^{20}$ The Blanco et al study was explain that the expansion of malignant precursor cells in chronic phase CML does not occur at the level of HSC. The high expression of GATA genes that play a role in the process of cell differentiation or Hox in $\mathrm{CD} 34^{+}$cells of CML patients and a smaller proportion of HSC lead to the activation of transcription and enhanced the ability of self-renewal capacity of these cells. This explains the increase in the proportion of myeloid erythroid progenitors (MEP), the lower the proportion of GMP and $\alpha$ receptor $\mathrm{CD} 34^{+} \&$ IL3 simultaneously with the increase in the high number of neutrophils and normal hemoglobin level, although the mechanism remains unclear. ${ }^{20}$ Briefly the expansion of the cells occurs in the mature neutrophils cells in the chronic phase as it fails to occur in the earlier stage.

\section{Conclusion}

This study shown correlation between the white blood cells count with level of Tyrosine Kinase enzyme, in untreated and treated CML patients.

\section{Acknowledgements}

We would like to thank for the suggestions of KurniaWahyudi from Epidemiology and Biostatistic for the statistic analysis and NurizzatunNafsi for the technical support. This work was partially supported by Faculty of Medicine, UniversitasPadjadjaran, Bandung Indonesia.

\section{References}

[1] E. Padron, LA Hazlehurst, J. Pinilla-Ibarz,"Molecular Pathogenesis of BCR-ABL in Chronic Myeloid Leukemia," In: HI Saba, editor. Advances in Malignant Hematology. $1^{\text {th }}$ Ed. West Sussex UK: Wiley Blackwell. A John Wiley \& Sons, Ltd., Publication, pp 62-70, 2011.

[2] R. Larson, SN Wolf,"Chronic Myeloid Leukemia", In: R. Lee, editor. Wintrobe Clinical Hematology. $10^{\text {th }}$ Ed.: Lipincot Williams \& Wilkins,Philadelphia, pp 234279, 2014.

[3] J.M. Goldman, JV Melo,"Chronic Myeloid LeukemiaAdvanceds in Biology and New Approaches to Treatment", New England Journal of Medicine (349), pp 1451-1464, 2003.

[4] MHMK Razelle Kurzrock,J Brian, Druker, Moshe Talpaz, "Philadelphia Chromosome-Positive Leukemias: From Basic Mechanisms to Molecular Therapeutics," Annals of Internal Medicine, 138(10), pp 819-831, 2003.

[5] R. Bhatia, JP Radich, "Chronic Myeloid Leukemia", In: Hoffman R, Benz EJ, Shattil S, Furie B, Silberstein LE, McGlave P, et al., editor. Hematology Basic Principles and Practice Edisi: Churchil Livingstone; 2008.

[6] S. Fröhling, H Döhner, "Chromosomal Abnormalities in Cancer", New England Journal of Medicine, (359), pp 722-34. 2008.

[7] D. Dingli, A. Traulsen, JM Pacheco, "Chronic Myeloid Leukemia: Origin, Development, Response to Therapy, and Relapse", Clinical Leukemia, 2(2), pp 133-139, 2008

[8] E. Kavalerchik, D. Goff, C. Jamieson, "Chronic Myeloid leukemia Stem Cells", Journal of Clinical Oncology, 2008 26(17), pp 2911-2915.

[9] S. O'Brien, C.N. Abboud, M. Akhtari, J. Altman, E. Berman, "Chronic Myelogenous Leukemia", Journal of the National Comprehensive Cancer Network, 10(1), pp 64-110. 2012

[10] C.M Croce, "Oncogenes and Cancer". The New England Journal of Medicine(358), pp 502-511, 2008.

[11] A. Charles, MD Schiffer, "BCR-ABL Tyrosine Kinase Inhibitors for Chronic Myelogenous Leukemia", The New England Journal of Medicine, (357), pp 258-65, 2007.

[12] M.K Paul, A.K. Mukhopadhyay, "Tyrosine kinaseRole and significance in Cancer", International Journal of Medical Sciences, 1(2), pp 101-15, 2004.

[13] SR Hubbard, JH Till, "Protein Tyrosine Kinase Structure anf Function", Annual Review Biochemistry (69), pp 373-98, 2000.

[14] A.S Tsao, H. Katarjian, M. Talpaz, "Review: STI-571 in Chronic Myelogenous Leukemia", British Journal of Hematology, (119), pp 15-24, 2002.

\section{Volume 5 Issue 7 July 2016}




\section{International Journal of Science and Research (IJSR) \\ ISSN (Online): 2319-7064}

Index Copernicus Value (2013): 6.14 | Impact Factor (2015): 6.391

[15] M. Serpa, S.S. Sanabani, P.E. Dorliac, Liacer, M. Conchon, T.D.M. Pereira, et al, "Molecular measurement of $B C R-A B L$ transcript variations in chronic myeloid leukemia patients in cytogenetic remission", BioMed Central Blood Disorders, 10(7), pp $1-8,2010$.

[16] C. Zhen, L. Wang, "Molecular Monitoring of Chronic Myeloid Leukemia International Standardization of BCR-ABL1 Quantitation", The Journal of Molecular Diagnostics 15(5), 2013.

[17] A.D. Bacco, K. Keeshan K, S.McKenna, G.C Thomas, "Molecular Abnormalities in Chronic Myeloid Leukemia: Deregulation of Cell Growth and Apoptosis", The Oncologist (5), pp 405-15, 2000.

[18] A.V. Hoffbrand, P.A.H Moss, "Chronic myeloid leukaemia" In: Hoffbrand's Essential Haematology. $7^{\text {th }}$ Ed. West Sussex, UK: John Wiley \& Sons, pp 156164, 2016.

[19] J.P. Radich, "Clinical Impact of Targeted Therapies in Myeloproliferative Neoplasms Chronic Myeloid Leukemia 2010: Where Are We Now and Where Can We Go?" In: Clinical Research Division FHCRC, editor. Seattle, WA, 2010.

[20] E. Diaz-Blanco, I Bruns, F Neumann, J. Fischer, T. Graef T, M. Rosskopf, et al., "Molecular signature of $\mathrm{CD}^{+} 4^{+}$hematopoietic stem and progenitor cells of patients with CML in chronic phase:, Leukemia. (21), pp 494-504, 2007.

Volume 5 Issue 7 July 2016 www.ijsr.net 